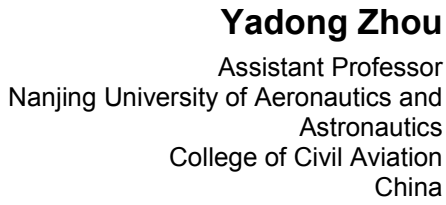

Yadong Zhou

China

\section{A Revisit to Normalization Methods for Purpose of Stress Mode Shapes}

In order to accurately interpret the results of modal analysis for the purpose of stress mode shapes (SMSs), this work revisits the normalization methods in computational structural dynamics. Firstly, the fundamental principle of structural dynamics analysis and mode of normalization were concisely introduced, and the critical parameters affecting SMSs were discussed. Secondly, the displacement and mass normalizations were applied to the case study of a beam structure. Detailed comparisons were considered between the SMSs and the conventional displacement mode shapes (DMSs) with different normalization methods. Lastly, some important characteristics were obtained. Present study can serve as an ongoing research effort aimed at evaluating both the SMSs and DMSs for future dynamic damage/failure analysis.

Keywords: modal analysis; stress mode shapes; normalization; dynamic stress; beam structure.

\section{INTRODUCTION}

It has been widely-accepted that both modal analysis and local stress response are critically important for mechanical systems by using numerical approaches, such as finite element modelling and analysis. Such procedures involve much knowledge of structural dynamics. In many applications, modal properties and dynamic stress analyses are frequently interplayed and have achieved much progress [1-8].

As the function of second derivatives of the classical displacement mode shapes (DMSs), strain mode shapes [9] have been applied in structural dynamic modelling, damage detection and dynamic design due to having high sensitivity [10-14]. In recent years, strain measurement based methods have been successfully developed to improve the local outperformance of model updating [15-17]. In the comparison of classic and strain experimental modal analysis (EMA), Kranjc et al. [18] pointed out that the advantage of strain EMA was the usefulness for an experimental investigation of the stress-strain response, which can be important for dynamic fatigue and damage detection. To obtain the mode shapes, the mass normalization can be performed with the classic EMA, but generally cannot be performed with strain EMA only. To handle this difficulty, Kranjc et al. [19] had proposed an approach based on the mass-change strategy. Roy et al. [20] used normalized fundamental DMSs and their normalized derivatives in damage localization. Sung et al. [21] proposed damage detection using the normalized curvature. Baghiee et al. [22] recently confirmed that modal curvatures were sensitive to the normalization methods in structural damage detection. As another second derivative, stress mode shapes (SMSs) have also

Received: March 2020, Accepted: April 2020

Correspondence to: Dr. Yadong Zhou

College of Civil Aviation,

29 Jiangjun Ave., Nanjing 211100, China

E-mail: yzhou@nuaa.edu.cn

doi: $10.5937 /$ fme2003516Z

(C) Faculty of Mechanical Engineering, Belgrade. All rights reserved been proposed for fast calculation of dynamic stresses $[23,24]$, of which the accuracy and efficiency are critically important for vibration fatigue in the frequency domain $[25,26]$. It has been verified that stress modal approaches could largely speed up the evaluation process of fatigue damage for mechanical structures subjected to random dynamic loads [27-30]. For dynamic stress modelling, Zhou [31] has recently proposed a method for local finite element refinement via SMSs information. These studies have preliminarily shown the promising utilization of SMSs in structural dynamics and damage evaluation.

As well known, the normalization methods have been well developed in computational modal analysis, which are naturally the scaling procedures that do not change the intrinsic dynamic characteristics of linear systems. However, in modal analysis for predicting structural damage severity/patterns or evaluating the critical hotspots of dangerous stresses, the scaling procedures that applied for mode shape normalization may have a significant influence. Under such background, this study revisits the normalization methods for SMSs consideration. Firstly, the fundamental theory was concisely reviewed. Secondly, a numerical case of a beam-type structure was investigated via finite element modelling, and comparisons were analyzed. Lastly, some conclusions were drawn.

\section{FUNDAMENTAL THEORY}

A continuous structural system can be discretized into a multiple degrees of freedom (DOFs) system utilizing finite element method, and the dynamic equation of the discretized system with $n$ DOFs is

$$
\mathbf{M} \ddot{\boldsymbol{u}}+\mathbf{C} \dot{\boldsymbol{u}}+\mathbf{K} \boldsymbol{u}=\boldsymbol{f}(t)
$$

where $\mathbf{M}, \mathbf{K}$, and $\mathbf{C}$ denote the $(n \times n)$ mass, stiffness, and damping matrices, and $\boldsymbol{u}$ is the $(n \times 1)$ displacement vector, and $\boldsymbol{f}$ is the $(n \times 1)$ loading excitation vector. Once the global system matrices are numerically constructed, the eigenvalue $\omega$ of the matrix 
system, and the resonant mode shape $\phi$, are defined by solving the following generalized undamped eigenvalue problem

$$
\mathbf{K} \phi=\omega^{2} \mathbf{M} \phi
$$

It can be seen that the mass $\mathbf{M}$ and stiffness $\mathbf{K}$ are the main global properties that affect the overall modal response of a system. The corresponding frequencies are $f=\omega / 2 \pi$. The two quantities can define the orthogonality of the eigenmodes with respect to the matrices $\mathbf{K}$ and $\mathbf{M}$, which are $\boldsymbol{\phi}_{r}^{T} \mathbf{K} \phi_{r}=k_{r}$ and $\boldsymbol{\phi}_{r}^{T} \mathbf{M} \phi_{r}=m_{r}$, respectively, where $k_{r}$ and $m_{r}$ are the $r$ th modal stiffness and modal mass respectively.

Substituting $\boldsymbol{u}(\mathrm{t})=\boldsymbol{\Phi} \boldsymbol{q}(\mathrm{t})$ into the dynamic equation, with $\boldsymbol{q}$ being the modal coordinate and $\boldsymbol{\Phi}(n \times n)$ being the DMSs matrix, premultiplying the result by $\boldsymbol{\Phi}^{T}$ and mass-normalizing the mode shapes $\tilde{\boldsymbol{\phi}}_{r}^{T}$ leading to unit modal mass $\tilde{m}_{r}$, it yields

$$
\ddot{\boldsymbol{q}}+\Gamma \dot{\boldsymbol{q}}+\Lambda^{2} \boldsymbol{q}=\Phi^{T} \boldsymbol{f}
$$

where $\tilde{\boldsymbol{\phi}}_{r}^{T} \mathbf{M} \tilde{\boldsymbol{\phi}}_{r}=1, \tilde{\boldsymbol{\phi}}_{r}^{T} \mathbf{M} \tilde{\boldsymbol{\phi}}_{s}=0(r \neq s), \boldsymbol{\Gamma}=\operatorname{diag}\left(2 \omega_{1} \zeta_{1}\right.$, $\left.2 \omega_{2} \zeta_{2}, \cdots, 2 \omega_{n} \zeta_{n}\right)$ and $\Lambda^{2}=\operatorname{diag}\left(\omega^{2}{ }_{1}, \omega^{2}{ }_{2}, \cdots, \omega^{2}{ }_{n}\right)$. It is the common practice to mass-normalize the mode shape vectors to uncouple the equations for dynamic response calculation. Herein, $\tilde{\phi}$ denotes the mass-normalized DMSs, while using $\bar{\phi}$ denotes the displacement-normalized DMSs.

For simplicity but without loss of generality, herein consider the beam-type structure with rectangular crosssection (length $L$, height $h$, width $b$ ). According to the basic theory of finite element method, the strain at any point within all structural elements can be expressed as $\boldsymbol{\varepsilon}=\mathbf{B T} \boldsymbol{u}$, where $\mathbf{T}$ is the transformation relationship between the elemental local coordinate and the structural global coordinate. For the straight beam system, the elemental coordinate agrees with the global coordinate, therefore, the strain mode (normal strain on the beam surface) along the $x$ - direction (longitudinal direction) is

$$
\phi_{x}^{\varepsilon}(x)=-(h / 2) \cdot \mathbf{B} \phi(x)
$$

where $h$ denotes the beam's height, $\mathbf{B}$ is the straindisplacement matrix. Furthermore, to be relevant with material strength such as vibration fatigue evaluation, modal stresses in a finite element model are related to the modal strains as shown below

$$
\phi_{x}^{\sigma}(x)=\mathbf{D} \phi_{x}^{\varepsilon}(x)
$$

where $\mathbf{D}$ is the elasticity matrix in finite element method, and $\phi_{x}^{\sigma}(x)$ is the SMSs along the longitudinal direction of the straight beam. Because of the matrix $\mathbf{B}$, the distribution of strain mode shapes in the structural model change with the modification of model parameters, especially the distribution near local abrupt change of the geometric details. Then, because of the matrix D, the SMSs also depend on the material properties. Derived from the DMSs, therefore, it can be seen that different normalization methods will yield different magnitudes of SMSs.

\section{FINITE ELEMENT MODELLING}

The model of a straight beam with rectangular crosssection is as shown in Fig. 1. In the finite element modelling, the encastre type were chosen for boundary condition settings on the two ends $\left(\mathrm{u}_{1}=\mathrm{u}_{2}=\mathrm{u}_{3}=\mathrm{ur}_{1}=\right.$ $\left.\operatorname{ur}_{2}=\mathrm{ur}_{3}=0\right)$, i.e., the clamped-clamped beam. The linear elastic material of titanium alloy was used with the following parameters: Young's modulus $E=108$ $\mathrm{GPa}$, the Poisson's ratio $v=0.34$, and the mass density $\rho$ $=4.5 \times 10^{3} \mathrm{~kg} / \mathrm{m}^{3}$. The in-plane and twist modes were kicked out, which are out of scope in present study. Therefore, only the bending modes in the $x z$ plane were considered, which results in displacements in the $z$ direction and normal strains in the $x$-direction. The 4node conventional shell elements with reduced integration were selected to mesh the model. Lanczos method was used in modal analysis.

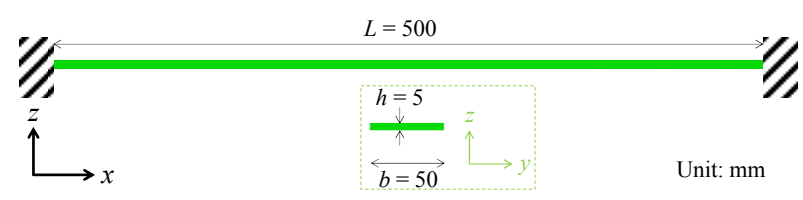

Figure 1. Geometry and boundary condition of the straight beam with rectangular cross section

\section{RESULTS AND DISCUSSION}

Fig. 2 gives the first six mode shapes of the beam, where the maximum deflection in the DMSs were normalized to unity. The displacement distribution ranges from -1 to 1 , with the colour from the blue to the red. For visualization purpose, the deformation scaling factor was set to 10 during outputting the mode shapes. Fig. 3 gives the first six mode shapes with mass normalization. From the comparison within the mass-normalization modes, it can be seen that the normalizing factor were different from each other, which was different from the case in displacement normalization. Because the deformation values are rather high in mass normalization, the deformation scaling factor was set to 0.1 during outputting the mode shapes for observation. Although different normalization methods were performed, it should be noted that the intrinsic dynamic property of DMSs do not change for present linear structure.

However, for purpose of SMSs application, different normalization methods maybe bring about some problems for the stress evaluation. Herein, the normal stress along the longitudinal direction of the beam is the principal component. Therefore, the $x$-direction stress on the top surface of the beam was chosen to compare. Fig. 4 gives the first six SMSs under displacement normalization, which exhibited a totally different distribution compared with the DMSs. For example, relative high magnitudes of SMSs distributed at the fixed end of the beam. Fig. 5 gives the first six SMSs under mass normalization. From the legend, we can see that the magnitudes of mass-normalized SMSs are extremely high, which can be ascribed to the large deflection in the mass-normalized DMSs. Fig. 6 compares the maximum magnitudes and the ratios of the SMSs with the two different normalizations, from which the detailed difference can be observed. 


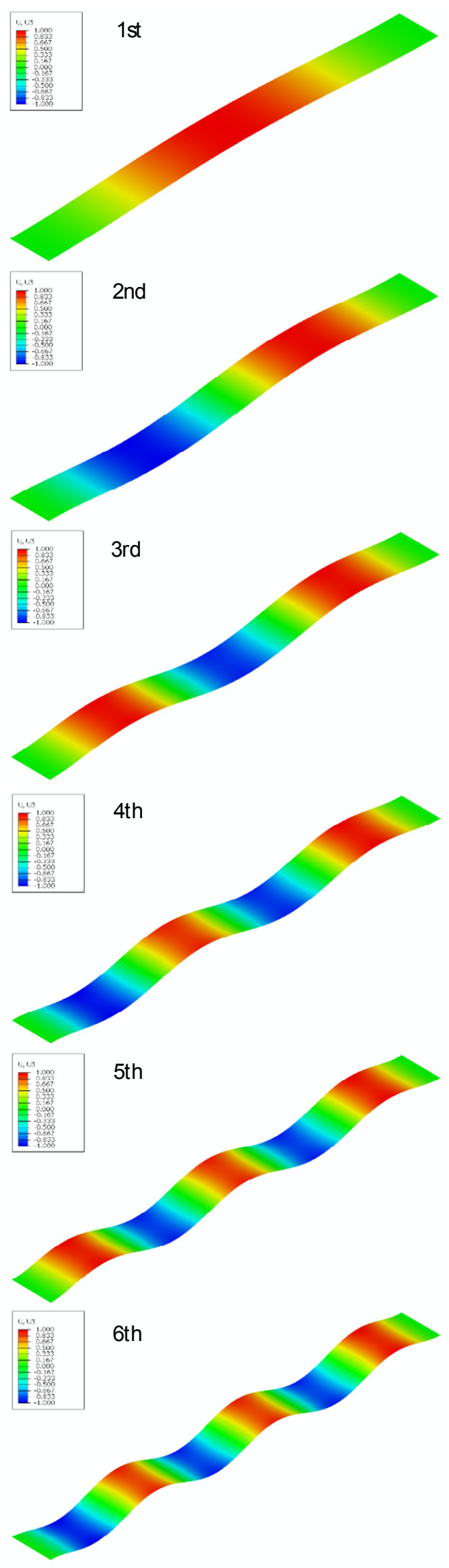

Figure 2. The first six DMSs of the beam with displacement normalization

In the dynamic response calculation, the mass normalization is generally used, but it is also faced with difficulty at certain situations, such as under the ambient excitation.

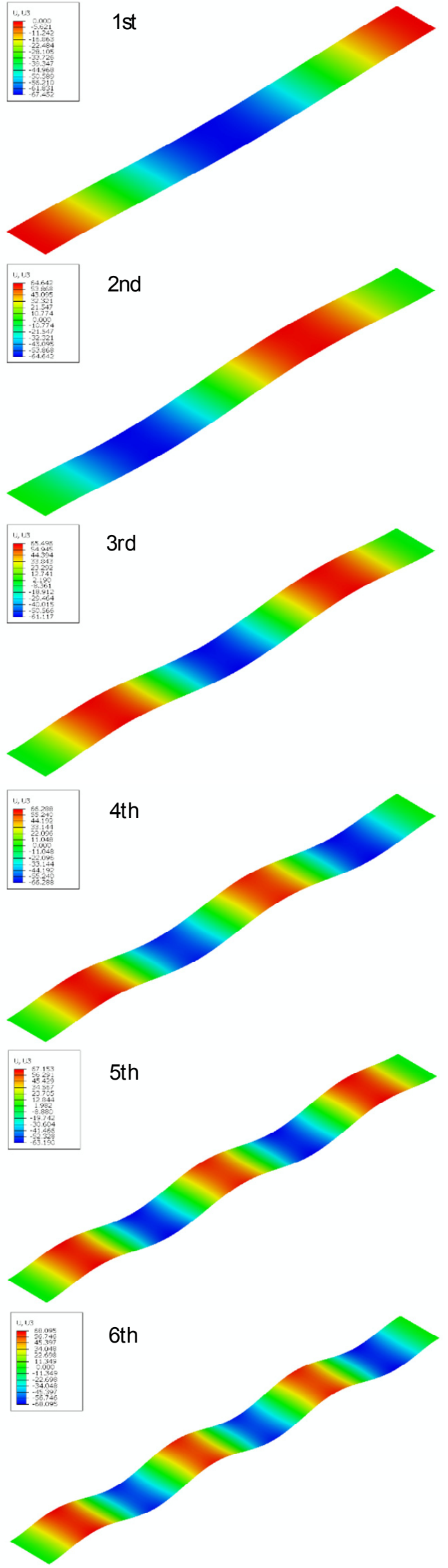

Figure 3. The first six DMSs of the beam with mass normalization 


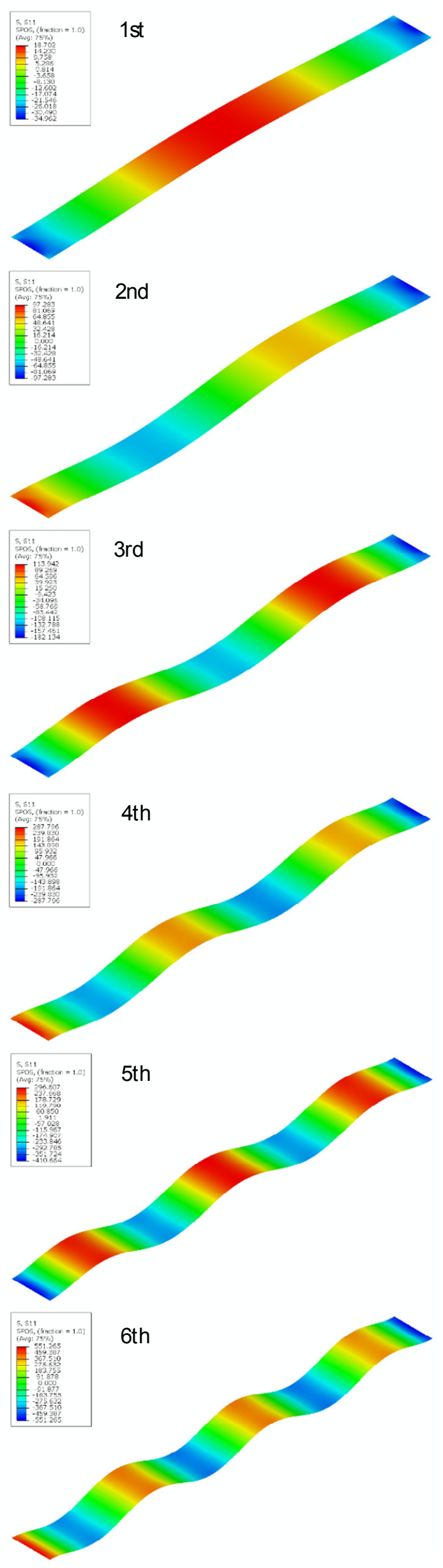

Figure 4. The first six SMSs of the beam with displacement normalization

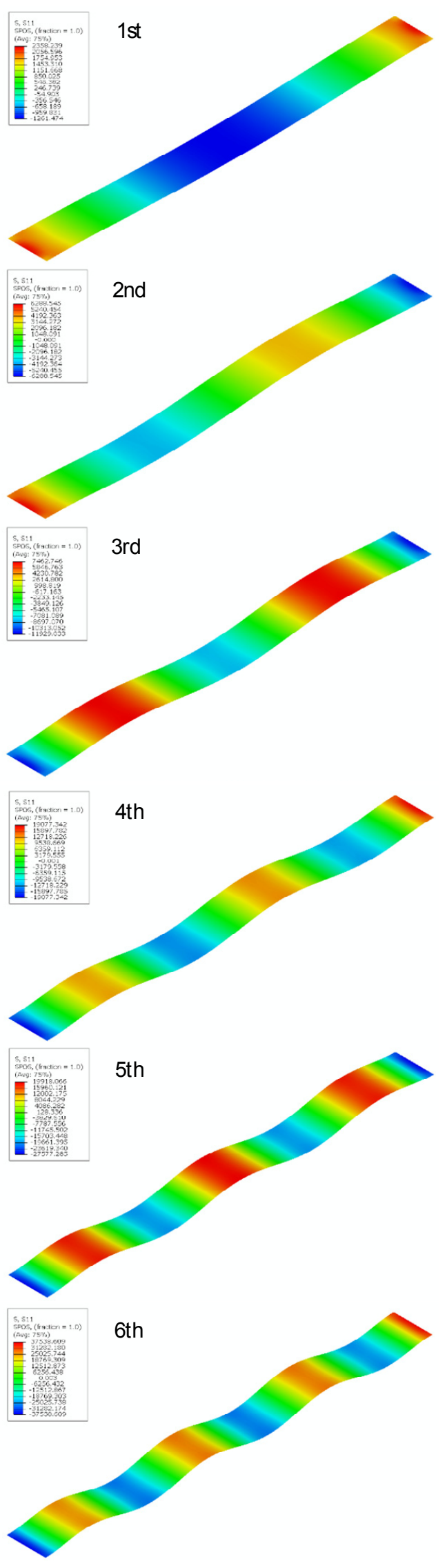

Figure 5. The first six SMSs of the beam with mass normalization

The modal effective mass is involved in the massnormalization method. Meanwhile, the scaling factor exhibits a discrepancy for different mass-normalized modes, such as $\approx 64.5$ at the $3 \mathrm{rd}$ mode while $\approx 68.1$ at 
the 6th mode for present simulation case. Therefore, additional attention should be paid to this fact when evaluating the SMSs for the localization of critical-butlocal stress hotspots as the vibration fatigue did [30]. Also, in displacement-normalization method it is convenient to observe and localize the critical stress points, which will be helpful to compare the stress states of different modes at the same maximum deformation. However, it is possible that some of the SMSs hotspots can be discarded because of the minor participation into the overall dynamic stress response, such as the highfrequency modes in the most situations. At such cases, the identification of predominant modes will be of critical importance.

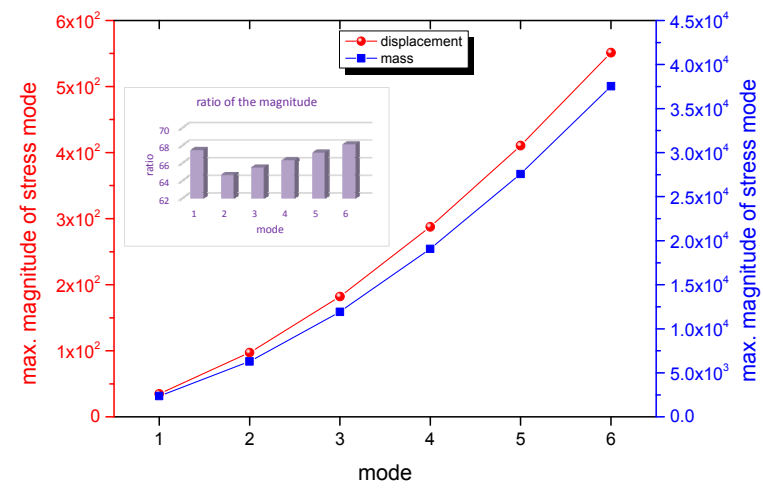

Figure 6. Maximum magnitudes and the ratios of the SMSs with the two normalizations

\section{CONCLUSION}

In this paper, an on-going effort on stress mode shapes (SMSs) was made, aiming at evaluating beam-like structures by using stress modal analysis performed via finite element method for numerical structural dynamics simulation. It is ascertained that differences exist between the two normalization methods, which have an influence on the visualization of the SMSs for dynamic stress and damage evaluation. It can be seen that both displacement and mass normalizations have their own advantages and drawbacks. It needs to mention that present structure was very simple. In the future study on complex structures, different normalizations for SMSs applications should be carefully examined and used.

\section{ACKNOWLEDGMENT}

The author greatly appreciates the editor and the two anonymous reviewers for their insightful comments and suggestions to improve the manuscript.

\section{REFERENCES}

[1] Trišović, N.: Eigenvalue sensitivity analysis in structural dynamics, FME Transactions, Vol. 35, No. 3, pp. 149-156, 2007.

[2] Yoon, G.H.: Structural topology optimization for frequency response problem using model reduction schemes, Comput Method Appl M, Vol. 199, 17441763, 2010.

[3] Garinis, D., Dinulović, M., and Rašuo, B.: Dynamic analysis of modified composite helicopter blade, FME Transactions, Vol. 40, No. 2, pp. 63-68, 2012.
[4] Lee, J.W., Yoon, G.H., and Jeong, S.H.: Topology optimization considering fatigue life in the frequency domain, Computers \& Mathematics with Applications, Vol. 70, No. 8, pp. 1852-1877, 2015.

[5] Li, H., Xia, H., Soliman, M., and Frangopol, D.M.: Bridge stress calculation based on the dynamic response of coupled train-bridge system, Eng Struct, Vol. 99, pp. 334-345, 2015.

[6] Mia, M.S., Islam, M.S., and Ghosh, U.: Modal Analysis of Cracked Cantilever Beam by Finite Element Simulation, Procedia Engineering, Vol. 194, pp. 509-516, 2017.

[7] Khazem, E., Abdullah, O., Sabri, L.: Steady-state and vibration analysis of a WindPACT $1.5-\mathrm{MW}$ turbine blade, FME Transactions, Vol. 47, No. 1, pp. 195-201, 2019.

[8] Svorcan, J., Trivković, Z., Ivanov, T., Baltić, M., Peković, O.: Multi-objective constrained optimizations of VAWT composite blades based on FEM and PSO, FME Transactions, Vol. 47, No. 4, pp. 887-893, 2019.

[9] Yam, L.Y., Leung, T.P., Li, D.B., and Xue, K.Z.: Theoretical and experimental study of modal strain analysis, Journal of Sound and Vibration, Vol. 191, No. 2, pp. 251-260, 1996.

[10]Lee, E.T., Rahmatalla, S., and Eun, H.C.: Damage detection by mixed measurements using accelerometers and strain gages, Smart Materials and Structures, Vol. 22, No. 7, pp. 075014, 2013.

[11]Zhou, Y., Wu, S., Trisovic, N., Fei, Q., and Tan, Z.: Modal Strain Based Method for Dynamic Design of Plate-Like Structures, Shock Vib, Vol. 2016, No. 2050627, pp. 1-10, 2016.

[12] Cheng, L., Busca, G., and Cigada, A.: Experimental strain modal analysis for beam-like structure by using distributed fiber optics and its damage detection, Measurement Science and Technology, Vol. 28, No. 7, pp. 074001, 2017.

[13]Loutas, T.H., and Bourikas, A.: Strain sensors optimal placement for vibration-based structural health monitoring. The effect of damage on the initially optimal configuration, J Sound Vib, Vol. 410, pp. 217-230, 2017.

[14]Hong, W. et al.: Comprehensive comparison of macro-strain mode and displacement mode based on different sensing technologies, Mech Syst Signal Pr, Vol. 50-51, pp. 563-579, 2015.

[15] Ha, J., Park, Y., and Park, Y.: Model Updating with Closed-Loop Strain Mode Shapes, Journal of Guidance, Control, and Dynamics, Vol. 30, No. 4, pp. 1206-1209, 2007.

[16] Park, H.S., Kim, Y., and Oh, B.K.: A model updating method with strain measurement from impact test for the safety of steel frame structures. Measurement. Vol. 102, pp. 220-229, 2017.

[17] Guo, N., Yang, Z., Wang, L., Bian, X.: A updating method using strain frequency response function with emphasis on local structure, Mech Syst Signal Pr, Vol. 115, pp. 637-656, 2019. 
[18]Kranjc, T., Slavič, J., and Boltežar, M.: A comparison of strain and classic experimental modal analysis, J Vib Control, Vol. 22, No. 2, pp. 371-381, 2016.

[19] Kranjc, T., Slavič, J., and Boltežar, M.: The mass normalization of the displacement and strain mode shapes in a strain experimental modal analysis using the mass-change strategy, J Sound Vib, Vol. 332, No. 26, pp. 6968-6981, 2013.

[20] Roy, K., Ray-Chaudhuri, S.: Fundamental mode shape and its derivatives in structural damage localization, J Sound Vib, Vol. 332, No. 21, pp. 55845593, 2013.

[21] Sung, S.H., Jung, H.J., and Jung, H.Y.: Damage detection for beam-like structures using the normalized curvature of a uniform load surface, J Sound Vib, Vol. 332, No. 6, pp. 1501-1519, 2013.

[22] Baghiee, N., Esfahani, M.R., and Moslem, K.: Damage detection of multi-girder bridge superstructure based on the modal strain approaches, Journal of Theoretical and Applied Vibration and Acoustics, Vol. 5, No. 1, pp. 21-42, 2019.

[23]Xie, C.H., Xue, P.: An accurate and efficient computational method for structural dynamic stresses under random loading, Aerosp Sci Technol, Vol. 59, pp. 11-17. 2016.

[24] Braccesi, C., Cianetti, F., and Tomassini, L.: Fast evaluation of stress state spectral moments, Int $\mathrm{J}$ Mech Sci, Vol. 127, pp. 4-9, 2017.

[25] Benasciutti, D.: Some analytical expressions to measure the accuracy of the "equivalent von Mises stress" in vibration multiaxial fatigue, J Sound Vib, Vol. 333, No. 18, pp. 4326-4340, 2014.

[26] Li, F., Wu, P., Zeng, J., Liu, C., Wu, H.: Vibration fatigue dynamic stress simulation under multi-load input condition: Application to metro lifeguard, Eng Fail Anal, Vol. 99, pp. 141-152, 2019.

[27] Braccesi, C., Cianetti, F., and Tomassini, L.: An innovative modal approach for frequency domain stress recovery and fatigue damage evaluation, Int $\mathrm{J}$ Fatigue, Vol. 91, pp. 382-396, 2016.

[28]Zhou, Y., Fei, Q., and Wu, S.: Utilization of modal stress approach in random-vibration fatigue evaluation. Proceedings of the Institution of Mechanical Engineers, Part G: Journal of Aerospace Engineering. Vol. 213, No. 14, pp. 2603-2615, 2017.

[29] Mršnik, M., Slavič, J., and Boltežar, M.: Vibration fatigue using modal decomposition, Mech Syst Signal Pr, Vol. 98, pp. 548-556, 2018.

[30]Zhou, Y., and Tao, J.: Theoretical and numerical investigation of stress mode shapes in multi-axial random fatigue, Mech Syst Signal Pr, Vol. 127, pp. 499-512, 2019.

[31]Zhou, Y.: Local FE refinement for accurate dynamic stress via modal information only, AIAA J, 2020, In press.

\section{NOMENCLATURE}

$\begin{array}{ll}b & \text { width of the beam } \\ \mathbf{B} & \text { strain-displacement matrix } \\ \mathbf{C} & \text { damping matrix } \\ \mathbf{D} & \text { elasticity matrix } \\ E & \text { Young's modulus } \\ \boldsymbol{f} & \text { loading vector } \\ f & \text { frequency in Hz } \\ h & \text { height of the beam } \\ \mathbf{K} & \text { stiffness matrix } \\ k_{r} & r \text { th modal stiffness } \\ L & \text { length of the beam } \\ m_{r} & r \text { th modal mass } \\ \tilde{m}_{r} & r \text { th unit modal mass } \\ n & \text { degrees of freedom } \\ \boldsymbol{q} & \text { modal coordinate } \\ \mathbf{T} & \text { transformation matrix } \\ t & \text { time } \\ \boldsymbol{u} & \text { displacement vector }\end{array}$

\section{Greek symbols}

$\begin{array}{ll}\omega_{r} & r \text { th modal frequency } \\ v & \text { Poisson's ratio } \\ \rho & \text { mass density } \\ \zeta_{r} & r \text { th modal damping ratio } \\ \phi & \text { displacement mode shape } \\ \tilde{\phi} & \text { mass-normalized mode } \\ \bar{\phi} & \text { displacement-normalized mode } \\ \phi_{x}^{\varepsilon} & \text { strain mode shape } \\ \phi_{x}^{\sigma} & \text { stress mode shape } \\ \boldsymbol{\Phi} & \text { displacement modal matrix }\end{array}$

\section{Superscripts}

$\begin{array}{ll}\varepsilon & \text { strain } \\ \sigma & \text { stress } \\ T & \text { transpose of matrix }\end{array}$

\section{ПОНОВНО РАЗМАТРАҢЕ МЕТОДА НОРМА- ЛИЗАЦИЈЕ РЕЖИМА ДЕЛОВАЊА НАПОНА}

$$
\text { J. Чоу }
$$

У циљу прецизног тумачења резултата анализе режима деловања напона, у раду се поновно разматра метод нормализације у рачунарској структурној динамици. Прво се уводе основни принципи анализе структурне динамике и начин нормализације а потом ce разматрају критични параметри код режима деловања напона. Друго, примењена је нормализација померања и масе код студије случаја структуре греде. Извршено је детаљно поређење режима деловања напона и конвенционалног режима померања са различитим методама нормализације. Добијене су неке значајне карактеристике. Истраживање може да послужи као основа за перманентну процену режима деловања напона и режима померања код анализе динамичког оштећења и/или отказа. 